\title{
Oropharyngeal Cancer pMX TNM Finding v6
}

National Cancer Institute

\section{Source}

National Cancer Institute. Oropharyngeal Cancer pMX TNM Finding v6. NCI Thesaurus. Code C64614.

Oropharyngeal cancer in which distant metastasis cannot be assessed. (from AJCC 6th Ed.) 